\title{
Effects of different potting growing media for Petunia grandiflora and Nicotiana alata Link \& Otto on photosynthetic capacity, leaf area, and flowering potential
}

\author{
Gheorghe Cristian Popescu $^{1 *}$, and Monica Popescu ${ }^{1}$
}

\begin{abstract}
Petunia grandiflora Juss. and Nicotiana alata Link \& Otto are two of the most widely spread plants on the market for annual potted ornamental plants. In order to identify the most adequate substrate formula we analyzed the effects of different potting growing media used for P. hybrida grandiflora 'Bravo' and N. alata 'Dinamo' on their photosynthetic capacity, leaf area, and flowering potential. Optimization of growing media formula for petunia and ornamental tobacco was performed by preparing four growing media mixing fallow soil (FS), Biolan peat (BP), acid peat (AP), leaf compost (C), and perlite $(\mathrm{P})$ in different proportions. The physiological potential of petunia and ornamental tobacco was investigated by photosynthesis and respiration rate and chlorophyll pigments in leaves, while the vegetative and flowering phenological stages were evaluated by number of leaves per plant, leaf area, number of flowers per plant and leaf area/flowers ratio. These measurements were significantly influenced by the different potting growing media used in this study. In the flowering stage, the highest photosynthesis rates $\left(8.612 \mu \mathrm{mol} \mathrm{CO}_{2} \mathrm{~m}^{-2} \mathrm{~s}^{-1}\right)$ as well as leaf area $\left(1.766 \mathrm{dm}^{2}\right)$ of petunias were obtained on growing media with $60 \%$ biolan peat, $30 \%$ acid peat and $10 \%$ perlite (BP60-AP30-P10). Flowering responses to growing conditions vary greatly among plants and the biggest number of ornamental tobacco flowers (22 flowers plant $\left.{ }^{-1}\right)$ was registered as an effect of BP60-AP30-P10 media. Growing media with the BP60-AP30-P10 formula seem to be the most adequate growth substrate to develop profitable crops for petunias and ornamental tobacco with high decorative value.
\end{abstract}

Key words: Flowering potential, growth substrate, photosynthesis.

\section{INTRODUCTION}

In recent years, in Romania, Petunia grandiflora Juss. and Nicotiana alata Link \& Otto have become popular annual bedding ornamental plants and economically profitable potted plants cultivated in different growth substrates in greenhouses. Petunias belong to the Solanaceae family and are used in landscape, private garden, and building decoration (Dole and Wilkins, 2004; Arancon et al., 2008; Francescangeli and Zagabria, 2008; Xu et al., 2010), pharmaceutical and cosmetics industry, and phytoremediation (Watharkar et al., 2013). Nicotiana alata (ornamental tobacco) has a good potential for commercial horticulture and is also used in pharmacy or to provide antifungal substances for pathogens control (Gaspar et al., 2014). In Romania the demand for annual ornamental plants is increasing.

Numerous studies in petunia species have been described previously. Warner (2010) documented in a greenhouse the influence of temperature and photoperiod on flowering and morphology of petunias. Gerats and

${ }^{1}$ University of Pitesti, Faculty of Science, Targu din Vale Street, $\mathrm{N}^{\circ} 1$, 110040, Pitesti, Romania.

*Corresponding author (christian_popescu2000@yahoo.com).

Received: 13 May 2014.

Accepted: 20 October 2014.

doi:10.4067/S0718-58392015000100003
Vandenbussche (2005) noted that petunias are often used for physiological studies because these annual plants are characterized by a short life cycle, color diversity, compact plant size, and relatively easy growth. Flowering capacity of petunia plants can be influenced by breeding and cultivation technology (Nishijima et al., 2006).

Zhanga et al. (2012) reported that the optimization of nutrient uptake and the influence of environmental factors are necessary to apply efficient cultural management for plant growth and development of petunia production. Growers typically use peat, perlite, vermiculite, sand, fallow land, and various organic and inorganic composted materials to prepare nutritious mixtures for floricultural plant production. Currently, in the entire world, different composting technologies are used for plant production; these are based on several types of wastes such as: municipal organic waste, sewage sludge, agricultural waste, animal manures, and some sorts of industrial waste (Castaldi et al., 2005; Tognetti et al., 2007; Hernández et al., 2010; Ntoulas et al., 2011). Humic acids are one of the natural organic compounds from the soil or composted materials which are included in growth substrates to increase substrate fertility, growth and yield for horticultural crops (Atiyeh et al., 2002; Arancon et al., 2006; Campitelli and Ceppi, 2008; Ahmad et al., 2013).

Arancon et al. (2008) studied the effects of different substitution rates for three types of vermicomposts 
(produced from cattle manure, food waste, and paper waste) on the germination, growth, and flowering of petunias in a soilless growth medium. Soilless growing media preparation from different organic materials and waste components is promoted as an alternative to agricultural land and as a way to eliminate the environmental impact of wastes (Garcia-Gomez et al., 2002; Di Benedetto et al., 2006; Civeira, 2010).

The production of potted ornamental plants is greatly influenced especially by growth medium components prepared in different proportions. The majority of ornamental plants are cultivated in greenhouses in growth substrates which usually contain different types of peat and perlite.

The purpose of this study was to evaluate the effect of some organic growth components used in commercial potting substrates for two popular ornamental plants: Petunia grandiflora and Nicotiana alata. In this paper we performed a comparative analysis of the influence of peat, leaf compost, perlite, and fallow land prepared in different proportions and compositions on plant growth and development. The current study aimed to explain the effect of growing media on these aspects by analyzing some physiological parameters, leaf area, and flowering potential of $P$. grandiflora and $N$. alata. In this experiment we optimized the growth substrate composition of $P$. grandiflora and $N$. alata in order to provide good agricultural practices to ornamental plant producers.

\section{MATERIALS AND METHODS}

\section{Plant material and culture conditions}

The study was conducted at the laboratories and greenhouse of the University of Pitesti, Pitesti, Romania. The plant material tested and evaluated in this research were two annual Solanaceae ornamental potted plants: Petunia grandiflora Juss. 'Bravo' and Nicotiana alata Link \& Otto 'Dinamo'. The cultivars were selected from the potted plants on the Romanian flower market, based on their popularity, availability, ornamental value, and commercial profitability. The chosen cultivars are characterized by flowering precocity, relatively compact size, uniformity and diversity of flower color, and abundance of flowers.

Several types of organic or inorganic materials such as biolan peat, acid peat, leaf compost, perlite, and fallow soil were evaluated as growing media components for ornamental plants. It is important to select an adequate growing medium to provide an essential tool for managing ornamental potted plants. Four growth substrates were prepared by mixing these growing media components in different proportions: $100 \%$ fallow soil (FS100); 30\% biolan peat $+60 \%$ acid peat $+10 \%$ perlite (BP30-AP60-P10); 60\% biolan peat $+30 \%$ acid peat + $10 \%$ perlite (BP60-AP30-P10); and $33 \%$ biolan peat $+33 \%$ leaf compost $+33 \%$ perlite (BP33-C33-P33)
Leaf compost is an organic product with a $\mathrm{pH}$ around 7 prepared by fermentation of plant debris from gardens and deciduous forests. Acid peat (Klasmann Baltica, Klasmann-Deilmann $\mathrm{GmbH}$, Geeste, Germany) has a $\mathrm{pH}$ around 4.2 and biolan peat is a natural resource usually with a $\mathrm{pH}$ around 6 (Biolan Oy, Kauttua, Finland). In Romania, fallow soil is often used as a component for growth substrates in horticulture and it is obtained from the top layer of soil on fallow land with perennial grasses. In order to stimulate rooting system development of each plant in the growth medium, the fertilizer Osmocote Exact (The Scotts Company Ltd., Godalming, Surrey, UK) was added when planting cuttings. Cuttings from selected cultivars were planted in plastic pots $\left(1\right.$ plant pot $\left.^{-1}\right)$ with a diameter of $12 \mathrm{~cm}$. The growing temperature in the greenhouse was $24 \pm 2{ }^{\circ} \mathrm{C}$. In this study we used leaf compost and fallow soil from private household, while acid peat and biolan peat are natural recourses provided by Klasmann-Deilmann and Biolan companies. In a factorial experimental design four horticultural growing media containing peat, leaf compost, perlite, and fallow land in different proportions and compositions were considered as treatments. The experiment was set according to a randomized complete block design with four treatments and five replicates, and a pot was the experimental unit for a total of 20 units for each studied species. Each replication consisted of one plant per pot.

\section{Measurements}

Photosynthetic capacity is an important indicator that explains the physiological activity of plants and the potential for vegetative development. As regards the assessment of the growth medium influence on plant physiological activity, we determined the effect of photosynthesis $\left(\mu \mathrm{mol} \mathrm{CO} \mathrm{Cm}^{-2} \mathrm{~s}^{-1}\right)$ and the respiration rate $\left(\mu \mathrm{mol} \mathrm{CO} \mathrm{C}^{-2} \mathrm{~s}^{-1}\right)$ in leaves, the content of chlorophyll a (Chl a, $\mathrm{mg} \mathrm{g}^{-1}$ ) and chlorophyll b (Chl b, $\left.\mathrm{mg} \mathrm{g}^{-1}\right)$, the $\mathrm{Chl} \mathrm{a/Chl} \mathrm{b}$ ratio in leaves, total leaf chlorophyll content $\left(\mathrm{mg} \mathrm{g}^{-1}\right)$, carotenoids (Car, $\mathrm{mg} \mathrm{g}^{-1}$ ), and the Chla+b/Car ratio in leaves.

Leaf gas exchange parameters were measured with a portable plant $\mathrm{CO}_{2}$ analysis package (S151 Infrared $\mathrm{CO}_{2}$ analyzer, Qubit Biology Inc., Ontario, Canada). Photosynthesis was measured in attached leaves maintained in an assimilation chamber. The $\mathrm{CO}_{2}$ concentration was measured with an infrared gas analyzer (IRGA). The difference between the initial $\mathrm{CO}_{2}$ concentration in the air and that in the air of the leaf chamber is used to measure the rate of photosynthesis. During testing, photosynthetic photon flux density (PPFD) was $1800 \mu \mathrm{mol} \mathrm{m} \mathrm{m}^{-2} \mathrm{~s}^{-1}$, air temperature was $24 \pm 2{ }^{\circ} \mathrm{C}$, and ambient relative humidity was between $60 \%$ and $65 \%$. Photosynthesis and respiration rates were expressed as $\mu \mathrm{mol} \mathrm{CO} \mathrm{Cm}^{-2} \mathrm{~s}^{-1}$.

Leaves were collected in early morning, and transported in an ice box to the laboratory for later determinations of 
assimilatory pigments content. Photosynthetic pigments were extracted in $80 \%$ acetone. Absorbance at 662,646 , and $440.5 \mathrm{~nm}$ was determined using a BOECO S-20VIS spectrophotometer (Boeckel \& Co, Hamburg, Germany). The amounts of chlorophyll and carotenoid pigments were calculated using Holm's formulas (Holm, 1954):

$$
\begin{aligned}
& \text { Chl } \mathrm{a}=9.78 \mathrm{~A}_{662}-0.99 \mathrm{~A}_{644} \\
& \mathrm{Chl} \mathrm{b}=21.4 \mathrm{~A}_{644}-4.65 \mathrm{~A}_{662} \\
& \text { Car }=4.69 \mathrm{~A}_{440.5}-0.267(\mathrm{Chl} \mathrm{a}+\mathrm{Chl} \mathrm{b})
\end{aligned}
$$

The total chlorophyll content was calculated as the sum of $\mathrm{Chl}$ a and $\mathrm{Chl} \mathrm{b}$. The results are obtained as $\mathrm{mg}$ pigments $\mathrm{g}^{-1} \mathrm{FW}$.

The effect of the growth substrates was also evaluated by counting number of leaves per each plant. The measurements for photosynthetic capacity, number of leaves, and leaf area were calculated at two major phenophases of plant life-cycle according to the $\mathrm{BBCH}$ scale (Meier, 2001): leafing stage and flowering stage. The influence of growth substrates on flowering potential was analyzed by counting number of flowers per plant and leaf area/flowers ratio. The measurements in the growth stage were made $4 \mathrm{wk}$ after planting while measurements in the flowering stage were recorded when plants gained ornamental value for selling, $12 \mathrm{wk}$ after planting.

\section{Statistical analysis}

A statistical analysis was performed using the ANOVA in the SPSS 16.0 software (IBM Corporation, Armonk, New York, USA) and means were compared using Duncan's multiple range tests at 5\% level. The results of this study are expressed as mean.

\section{RESULTS}

The results of the analysis regarding the effects produced by the growth substrates of 'Bravo' and 'Dinamo' on photosynthesis and respiration rate are presented in Table 1. Petunias and ornamental tobacco grown in media with $100 \%$ fallow soil had the lowest respiration and photosynthesis rates for both leafing and flowering stages. The respiration and photosynthesis rates for both petunias and ornamental tobacco were greatly influenced by the growth substrate with the BP60-AP30-P10 formula. No significant differences regarding the respiration rate of petunias were found between the BP60-AP30-P10 and BP33-C33-P33 media in the flowering stage. The photosynthesis process in the flowering stage for 'Dinamo' showed significant differences between all growth media (Table 1).

Growth substrates used for $P$. grandiflora 'Bravo' and N. alata 'Dinamo' did not show significant differences in terms of $\mathrm{Chl}$ a and $\mathrm{Chl} \mathrm{b}$ content between the BP30AP60-P10, BP60-AP30-P10, and BP33-C33-P33 media (Table 2). The chlorophyll content increased with increasing amount of biolan peat and was negatively influenced by FS100 media. In this study, for both ornamental species, the content of chlorophyll a and $b$ was higher in the flowering stage of the plants. The Chl $\mathrm{a} / \mathrm{Chl} \mathrm{b}$ ratio in leaves of petunias was enhanced by the medium containing FS100, while the $\mathrm{Chl} \mathrm{a} / \mathrm{Chl} \mathrm{b}$ ratio in ornamental tobacco showed higher values in growth media with different proportions of peat (Table 2).

The growth substrates used in this study had a higher effect at flowering stage than leafing stage for total leaf chlorophyll content for both petunia and ornamental tobacco plants (Table 3). Total leaf chlorophyll content

Table 1. Effect of growth substrate on photosynthesis and respiration

\begin{tabular}{|c|c|c|c|c|c|}
\hline \multirow[b]{2}{*}{ Cultivars } & \multirow[b]{2}{*}{$\begin{array}{l}\text { Growth } \\
\text { substrates }\end{array}$} & \multicolumn{2}{|c|}{ Photosynthesis rate } & \multicolumn{2}{|c|}{ Respiration rate } \\
\hline & & $\begin{array}{l}\text { Leafing } \\
\text { stage }\end{array}$ & $\begin{array}{c}\text { Flowering } \\
\text { stage }\end{array}$ & $\begin{array}{l}\text { Leafing } \\
\text { stage }\end{array}$ & $\begin{array}{c}\text { Flowering } \\
\text { stage }\end{array}$ \\
\hline & & \multicolumn{2}{|c|}{$\mu \mathrm{mol} \mathrm{CO} 2 \mathrm{~m}^{-2} \mathrm{~s}^{-1}$} & \multicolumn{2}{|c|}{$\mu \mathrm{mol} \mathrm{CO} 2 \mathrm{~m}^{-2} \mathrm{~s}^{-1}$} \\
\hline Petunia grandiflora & FS100 & $3.008 \mathrm{c}$ & $3.105 \mathrm{~d}$ & $0.812 \mathrm{c}$ & $1.005 \mathrm{c}$ \\
\hline \multirow[t]{3}{*}{ 'Bravo' } & BP30-AP60-P10 & $0 \quad 5.114 b$ & $7.125 \mathrm{c}$ & $1.815 \mathrm{~b}$ & $2.104 b$ \\
\hline & BP60-AP30-P10 & $07.505 \mathrm{a}$ & $8.612 \mathrm{a}$ & $2.442 \mathrm{a}$ & $3.125 \mathrm{a}$ \\
\hline & BP33-C33-P33 & $6.122 b$ & $8.005 b$ & $1.912 b$ & $2.845 \mathrm{a}$ \\
\hline Nicotiana alata & FS100 & $2.881 \mathrm{c}$ & $3.002 \mathrm{~d}$ & $0.618 \mathrm{c}$ & $1.125 \mathrm{~d}$ \\
\hline \multirow[t]{3}{*}{ 'Dinamo' } & BP30-AP60-P10 & $04.138 b$ & $6.445 c$ & $1.613 \mathrm{~b}$ & $2.004 \mathrm{c}$ \\
\hline & BP60-AP30-P10 & $07.722 \mathrm{a}$ & $8.851 \mathrm{a}$ & $2.660 \mathrm{a}$ & $3.425 \mathrm{a}$ \\
\hline & BP33-C33-P33 & $6.551 \mathrm{~b}$ & $8.105 b$ & $1.885 b$ & $2.704 b$ \\
\hline
\end{tabular}
rate in leaves of Petunia grandiflora 'Bravo' and Nicotiana alata 'Dinamo'.

Mean values followed by the same letter are not significantly different according to Duncan's multiple range test $(\mathrm{P}<0.05)$.

FS100: $100 \%$ fallow soil; BP30-AP60-P10: $30 \%$ biolan peat $+60 \%$ acid peat + $10 \%$ perlite; BP60-AP30-P10: $60 \%$ biolan peat $+30 \%$ acid peat $+10 \%$ perlite; and BP33-C33-P33: $33 \%$ biolan peat $+33 \%$ leaf compost $+33 \%$ perlite.

\begin{tabular}{|c|c|c|c|c|c|c|c|}
\hline \multirow[b]{2}{*}{ Cultivars } & \multirow[b]{2}{*}{ Growth substrates } & \multicolumn{2}{|c|}{ Chlorophyll a } & \multicolumn{2}{|c|}{ Chlorophyll b } & \multicolumn{2}{|c|}{$\mathrm{Chl} \mathrm{a/Chl} \mathrm{b} \mathrm{ratio}$} \\
\hline & & $\begin{array}{c}\text { Leafing } \\
\text { stage }\end{array}$ & $\begin{array}{c}\text { Flowering } \\
\text { stage }\end{array}$ & $\begin{array}{c}\text { Leafing } \\
\text { stage }\end{array}$ & $\begin{array}{c}\text { Flowering } \\
\text { stage }\end{array}$ & $\begin{array}{c}\text { Leafing } \\
\text { stage }\end{array}$ & $\begin{array}{c}\text { Flowering } \\
\text { stage }\end{array}$ \\
\hline & & & & & & & 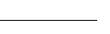 \\
\hline \multirow{4}{*}{ Petunia grandiflora 'Bravo' } & FS100 & $6.108 \mathrm{~b}$ & $6.812 b$ & $2.871 \mathrm{~b}$ & $2.912 b$ & $2.127 \mathrm{a}$ & $2.339 a$ \\
\hline & BP30-AP60-P10 & $8.516 a$ & $10.005 \mathrm{a}$ & $4.009 \mathrm{a}$ & $4.506 \mathrm{a}$ & $2.124 \mathrm{a}$ & $2.220 \mathrm{~b}$ \\
\hline & BP60-AP30-P10 & $8.646 \mathrm{a}$ & $10.105 \mathrm{a}$ & $4.105 \mathrm{a}$ & $4.668 \mathrm{a}$ & $2.106 \mathrm{a}$ & $2.164 b$ \\
\hline & BP33-C33-P33 & $8.012 \mathrm{a}$ & $9.814 \mathrm{a}$ & $4.200 \mathrm{a}$ & $4.738 \mathrm{a}$ & $1.907 \mathrm{~b}$ & $2.071 \mathrm{c}$ \\
\hline \multirow[t]{4}{*}{ Nicotiana alata 'Dinamo' } & FS100 & $4.238 b$ & $4.844 \mathrm{~b}$ & $1.902 \mathrm{~b}$ & $1.998 \mathrm{~b}$ & $2.228 \mathrm{a}$ & $2.424 b$ \\
\hline & BP30-AP60-P10 & $6.226 \mathrm{a}$ & $9.014 \mathrm{a}$ & $3.216 \mathrm{a}$ & $3.412 \mathrm{a}$ & $1.935 \mathrm{c}$ & $2.641 \mathrm{a}$ \\
\hline & BP60-AP30-P10 & $6.425 \mathrm{a}$ & $9.221 \mathrm{a}$ & $3.142 \mathrm{a}$ & $3.514 \mathrm{a}$ & $2.044 \mathrm{~b}$ & $2.624 \mathrm{a}$ \\
\hline & BP33-C33-P33 & $6.315 \mathrm{a}$ & $9.012 \mathrm{a}$ & $3.311 \mathrm{a}$ & $3.662 \mathrm{a}$ & $1.907 \mathrm{c}$ & $2.461 \mathrm{~b}$ \\
\hline
\end{tabular}

Table 2. Effect of growth substrate on chlorophyll a, chlorophyll b, and $\mathrm{Chl}$ a/Chl b ratio in leaves of Petunia grandiflora 'Bravo' and Nicotiana alata 'Dinamo'.

Mean values followed by the same letter are not significantly different according to Duncan's multiple range test $(\mathrm{P}<0.05)$.

FS100: $100 \%$ fallow soil; BP30-AP60-P10: $30 \%$ biolan peat $+60 \%$ acid peat $+10 \%$ perlite; BP60-AP30-P10: $60 \%$ biolan peat $+30 \%$ acid peat $+10 \%$ perlite; and BP33-C33-P33: $33 \%$ biolan peat $+33 \%$ leaf compost $+33 \%$ perlite. 
Table 3. Effect of growth substrate on total leaf chlorophyll content, carotenoids (Car), and Chla+b/Car ratio in the leaves of Petunia grandiflora 'Bravo' and Nicotiana alata 'Dinamo'.

\begin{tabular}{|c|c|c|c|c|c|c|c|}
\hline \multirow[b]{2}{*}{ Cultivars } & \multirow[b]{2}{*}{ Growth substrates } & \multicolumn{2}{|c|}{ Total leaf chlorophyll content } & \multicolumn{2}{|c|}{ Carotenoids } & \multicolumn{2}{|c|}{ Chla+b/Car ratio } \\
\hline & & $\begin{array}{l}\text { Leafing } \\
\text { stage }\end{array}$ & $\begin{array}{c}\text { Flowering } \\
\text { stage }\end{array}$ & $\begin{array}{l}\text { Leafing } \\
\text { stage }\end{array}$ & $\begin{array}{c}\text { Flowering } \\
\text { stage }\end{array}$ & $\begin{array}{l}\text { Leafing } \\
\text { stage }\end{array}$ & $\begin{array}{l}\text { Flowering } \\
\text { stage }\end{array}$ \\
\hline & FS100 & $8.979 \mathrm{c}$ & $9.724 c$ & $0.723 c$ & $0.965 \mathrm{c}$ & $12419 a$ & $10.076 a$ \\
\hline \multirow{3}{*}{ Petunia grandiflora 'Bravo' } & BP30-AP60-P10 & $12.525 b$ & $14.511 \mathrm{~b}$ & $1.525 \mathrm{~b}$ & $1.942 \mathrm{~b}$ & $8.213 \mathrm{ab}$ & $7.472 \mathrm{bc}$ \\
\hline & BP60-AP30-P10 & $12.751 \mathrm{a}$ & $14.773 \mathrm{a}$ & $1.755 \mathrm{a}$ & $2.214 \mathrm{a}$ & $7.265 b$ & $6.672 b$ \\
\hline & BP33-C33-P33 & $12.212 \mathrm{~b}$ & $14.552 b$ & $1.612 b$ & $2.005 b$ & $7.575 b$ & $7.257 \mathrm{bc}$ \\
\hline \multirow[t]{4}{*}{ Nicotiana alata 'Dinamo' } & FS100 & $6.140 \mathrm{c}$ & $6.842 \mathrm{c}$ & $0.778 \mathrm{c}$ & $0.884 \mathrm{c}$ & $7.892 \mathrm{a}$ & $7.739 a$ \\
\hline & BP30-AP60-P10 & $9.442 b$ & $12.426 \mathrm{~b}$ & $1.233 b$ & $1.667 \mathrm{~b}$ & $7.657 \mathrm{a}$ & $7.454 b$ \\
\hline & BP60-AP30-P10 & $9.567 \mathrm{a}$ & $12.735 \mathrm{a}$ & $1.589 \mathrm{a}$ & $2.103 \mathrm{a}$ & $6.020 \mathrm{~b}$ & $6.055 \mathrm{c}$ \\
\hline & BP33-C33-P33 & $9.626 \mathrm{a}$ & $12.674 \mathrm{a}$ & $1.491 b$ & $1.714 b$ & $6.456 b$ & $7.394 b$ \\
\hline
\end{tabular}

Mean values followed by the same letter are not significantly different according to Duncan's multiple range test $(\mathrm{P}<0.05)$.

FS100: $100 \%$ fallow soil; BP30-AP60-P10: $30 \%$ biolan peat $+60 \%$ acid peat $+10 \%$ perlite; BP60-AP30-P10: $60 \%$ biolan peat $+30 \%$ acid peat $+10 \%$ perlite; and BP33-C33-P33: $33 \%$ biolan peat $+33 \%$ leaf compost $+33 \%$ perlite.

of $N$. alata plants cultured in BP60-AP30-P10 and BP33C33-P33 media did not show any significant differences. Regarding the influence of growth media on carotenoid pigments in the studied species, there were no significant differences between applying BP30-AP60-P10 medium and BP33-C33-P33 medium, but we found significant differences between BP60-AP30-P10 media and all other culture media. The Chla+b/Car ratio measured in leaves of P. grandiflora 'Bravo' and N. alata 'Dinamo' was higher in the medium FS100; the rate of this indicator was reduced by the presence of the BP60-AP30-P10 medium (Table 3).

The maximum vegetative growth potential showed by number of leaves per plant and leaf area was found in plants grown in media BP60-AP30-P10 (Table 4). Petunia grandiflora had the lowest number of leaves and leaf area in growth substrates with fallow soil while the BP60AP30-P10 medium had the biggest effect. In petunias, no significant differences were found in terms of leaf area in the flowering stages between the BP60-AP30-P10 and BP33-C33-P33 media, while significant differences were showed between the BP30-AP60-P10 and FS100 media (Table 4). The ornamental tobacco plant cultured in the BP60-AP30-P10 medium had a higher foliar area, while the lowest foliar area was induced by the medium with

Table 4. Effect of growth substrate on number of leaves per plant and leaf area of Petunia grandiflora 'Bravo' and Nicotiana alata 'Dinamo'.

\begin{tabular}{|c|c|c|c|c|c|}
\hline \multirow[b]{2}{*}{ Cultivars } & \multirow[b]{2}{*}{$\begin{array}{c}\text { Growth } \\
\text { substrates }\end{array}$} & \multicolumn{2}{|c|}{$\begin{array}{c}\text { Number of leaves } \\
\text { per plant }\end{array}$} & \multicolumn{2}{|c|}{ Leaf area } \\
\hline & & $\begin{array}{l}\text { Leafing } \\
\text { stage }\end{array}$ & $\begin{array}{l}\text { Flowering } \\
\text { stage }\end{array}$ & $\begin{array}{l}\text { Leafing } \\
\text { stage }\end{array}$ & $\begin{array}{c}\text { Flowering } \\
\text { stage }\end{array}$ \\
\hline \multirow{5}{*}{$\begin{array}{l}\text { Petunia grandiflora } \\
\text { 'Bravo' }\end{array}$} & & & & \multicolumn{2}{|c|}{$-\mathrm{dm}^{2}$} \\
\hline & FS100 & $10 \mathrm{c}$ & $14 \mathrm{c}$ & $0.154 \mathrm{c}$ & $0.323 \mathrm{c}$ \\
\hline & BP30-AP60-P10 & $\begin{array}{ll}0 & 16 \mathrm{~b}\end{array}$ & $32 \mathrm{~b}$ & $0.659 \mathrm{~b}$ & $1.318 \mathrm{~b}$ \\
\hline & ВР60-AP30-P10 & $020 \mathrm{a}$ & $40 \mathrm{a}$ & $1.027 \mathrm{a}$ & $1.766 \mathrm{a}$ \\
\hline & BP33-C33-P33 & $19 \mathrm{ab}$ & $33 b$ & $0.761 \mathrm{~b}$ & $1.644 \mathrm{a}$ \\
\hline \multirow{4}{*}{$\begin{array}{l}\text { Nicotiana alata } \\
\text { 'Dinamo' }\end{array}$} & FS100 & $9 \mathrm{c}$ & $12 \mathrm{c}$ & $0.307 \mathrm{c}$ & $0.527 \mathrm{c}$ \\
\hline & BP30-A & $\begin{array}{lll}0 & 15 b\end{array}$ & $23 \mathrm{~b}$ & $0.811 \mathrm{~b}$ & $1.744 \mathrm{~b}$ \\
\hline & BP60-AP30-P10 & $\begin{array}{lll}0 & 17 \mathrm{a}\end{array}$ & 36 & $1.087 \mathrm{ab}$ & $2.345 \mathrm{a}$ \\
\hline & BP33-C33-P33 & $18 \mathrm{a}$ & $21 \mathrm{~b}$ & $1.200 \mathrm{a}$ & $2.238 \mathrm{a}$ \\
\hline
\end{tabular}

Mean values followed by the same letter are not significantly different according to Duncan's multiple range test $(\mathrm{P}<0.05)$.

FS100: $100 \%$ fallow soil; BP30-AP60-P10: $30 \%$ biolan peat $+60 \%$ acid peat + $10 \%$ perlite; $\mathrm{BP} 60-\mathrm{AP} 30-\mathrm{P} 10: 60 \%$ biolan peat $+30 \%$ acid peat $+10 \%$ perlite; and BP33-C33-P33: $33 \%$ biolan peat $+33 \%$ leaf compost $+33 \%$ perlite. fallow soil. Significant differences in leaf area were found between the FS100 and BP30-AP60-P10 at flowering stage of $N$. alata. The bigger number of leaves is directly correlated with the leaf area of petunia and ornamental tobacco in all culture substrates (Table 4).

The BP60-AP30-P10 and BP33-C33-P33 substrates were the most adequate for formation of flowers; growth substrates for $P$. grandiflora 'Bravo' did not show significant differences in number of flowers per plant between the BP30-AP60-P10, BP60-AP30-P10 and BP33-C33-P33 media, while for N. alata we did not find significant differences between BP30-AP60-P10 and BP33-C33-P33 media (Table 5).

Leaf area/flowers ratio is an important tool that can characterize the ornamental value and the flowering potential according to the foliar surface of the plant. Analyzing the leaf area/flowers ratio, in this study we observed significant differences between the FS100, BP30-AP60-P10, and BP33-C33-P33 media in the case of P. grandiflora 'Bravo'. Petunia grandiflora 'Bravo' registered the highest value of leaf area/flowers ratio in the BP33-C33-P33 growing medium and the lowest value in the FS100 growth substrates. Growth substrates with $30 \%$ or $60 \%$ peat proportion for P. grandiflora 'Bravo' did not show significant differences. The higher value of leaf area/flowers ratio was induced by plants of $N$. alata cultured in FS100 media, while the lower value of leaf

Table 5. Effect of growth substrate on number of flowers per plant and leaf area/flowers ratio of Petunia grandiflora 'Bravo' and Nicotiana alata 'Dinamo'.

\begin{tabular}{llcc}
\hline Cultivars & \multicolumn{1}{c}{$\begin{array}{c}\text { Growth } \\
\text { substrates }\end{array}$} & $\begin{array}{c}\text { Number of } \\
\text { flowers per } \\
\text { plant }\end{array}$ & $\begin{array}{c}\text { Leaf area/ } \\
\text { flowers } \\
\text { ratio }\end{array}$ \\
\hline Petunia grandiflora 'Bravo' & FS100 & $2 \mathrm{~b}$ & $0.161 \mathrm{c}$ \\
& BP30-AP60-P10 & $5 \mathrm{a}$ & $0.263 \mathrm{~b}$ \\
& BP60-AP30-P10 & $6 \mathrm{a}$ & $0.294 \mathrm{~b}$ \\
& BP33-C33-P33 & $5 \mathrm{a}$ & $0.328 \mathrm{a}$ \\
Nicotiana alata 'Dinamo' & FS100 & $3 \mathrm{c}$ & $0.175 \mathrm{a}$ \\
& BP30-AP60-P10 & $12 \mathrm{~b}$ & $0.145 \mathrm{ab}$ \\
& BP60-AP30-P10 & $22 \mathrm{a}$ & $0.106 \mathrm{c}$ \\
& BP33-C33-P33 & $16 \mathrm{~b}$ & $0.139 \mathrm{~b}$ \\
\hline
\end{tabular}

Mean values followed by the same letter are not significantly different according to Duncan's multiple range test $(\mathrm{P}<0.05)$.

FS100: $100 \%$ fallow soil; BP30-AP60-P10: $30 \%$ biolan peat $+60 \%$ acid peat + $10 \%$ perlite; BP60-AP30-P10: $60 \%$ biolan peat $+30 \%$ acid peat $+10 \%$ perlite and BP33-C33-P33: $33 \%$ biolan peat $+33 \%$ leaf compost $+33 \%$ perlite. 
area/flowers ratio was produced by plants of $N$. alata growing in BP60-AP30-P10 media. The FS100, BP60AP30-P10, and BP33-C33-P33 media had a significant effect on the leaf area/flowers ratio of $N$. alata 'Dinamo' (Table 5).

\section{DISCUSSION}

Studies regarding soilless substrates have been performed on many important floricultural plants such as petunias (Arancon et al., 2008), begonias, tagetes (Grigatti et al., 2007), impatiens (Chavez et al., 2008), roses (Nazari et al., 2009), poinsettias (Papafotiou et al., 2004), gladioli (Ahmad et al., 2013) and antirrhinums (Mehmood et al., 2013). Growth substrates influenced the photosynthetic capacity, leaf area, and flowering potential, which play an important role in growth and development processes of plants. A very important aspect in the production of potted ornamental plants is the controlled and induced vegetative and floral growth by horticultural practices. Many studies on the use of organic or inorganic components for enhanced growth in soilless cultures have been reported by researchers (Ribeiro et al., 2007; Zaller, 2007; Arancon et al., 2008; Bustamante et al., 2008; Bachman and Metzger, 2008; Medina et al., 2009; Hernández et al., 2010; Ntoulas et al., 2011). Arancon et al. (2008) reported that petunia seeds germinated faster in growth substrates with larger amounts of vermicomposts. Petunias grown in substitutions of 20\%, 30\%, and $40 \%$ of food waste vermicomposts into a soilless growth medium, in substitutions of $20 \%, 30 \%$, and $40 \%$ cattle manure vermicompost or in a mixture of $40 \%$ paper waste vermicompost and $60 \%$ commercial soilless growth medium produced significantly more flowers (Arancon et al., 2008). Grigatti et al. (2007) investigated the potential effect of growing substrates with white peat and 25-50$75-100 \%$ green waste and sewage sludge $(80 \%+20 \%$ $\mathrm{v} / \mathrm{v})$ compost for Begonia semperflorens 'Bellavista F1', Salvia splendens 'Maestro' and Tagetepatula $\times$ erecta 'Zenith Lemon Yellow' and noted that the medium with $25 \%$ compost produced the highest number of flowers in all the species. Chavez et al. (2008) studied the influence on plant growth of alternative soilless media based on river waste and Sphagnum spp. and Carex spp. from Argentinean peatlands with different proportions of perlite and vermiculite in Petunia $\times$ hybrid $a$ and Impatiens wallerana. They reported that river waste and Carex peat are adequate alternatives to Sphagnum peat from the Northern Hemisphere to grow high quality plants. The highest dry weight of $I$. wallerana was observed in plants cultured in media containing Carex peat $(70 \%)+$ Perlite $(20 \%)+$ Vermiculite $(10 \%)$, while in Petunia hybrid, at harvest time ( $65 \mathrm{~d}$ from transplant), the highest dry weight was induced by growing media with Carex peat $(40 \%)+$ river waste $(40 \%)+$ perlite $(10 \%)+$ vermiculite $(10 \%)$ (Chavez et al., 2008).
Medina et al. (2009) showed the possibility of using spent mushroom substrates in the production of horticultural seedlings replacing part of the peat in the growing media. Papafotiou et al. (2005) reported the behavior of Syngonium podophyllum, Codiaeum variegatum and Ficus benjamina on media containing olive-mill waste compost, sphagnum peat, and perlite in different formulas and suggested that olive-mill waste compost can replace $25 \%$ of peat in a potting media for S. podophyllum and $75 \%$ of peat in C. variegatum and F. benjamina. Benito et al. (2006) evaluated the use of pruning wastes compost for ornamental plants production of Lolium perenne L. and Cupressus sempervirens L. by preparing six growth substrates containing pruning wastes compost, peat, ground leaves, sand, and spent mushroom compost in different proportions and concluded that the pruning wastes compost could be used as a growing media component. The addition of $10 \%$ and $20 \%$ vermicompost of pig manure origin into a commercial potting substrate had positive effects in dry shoot tissue and leaf area of marigolds, tomatoes, green peppers, and cornflowers (Bachman and Metzger, 2008).

Four different formula substrates with compost obtained from forestry wastes and solid phase of pig slurry and peat were tested to evaluate the capacity of plant growth media for the production of tomato and lettuce seedlings. The presence of compost contributed to earlier seed emergence; the greatest root dry weight and number of leaves occurred on media with $100 \%$ compost obtained from forestry wastes and solid phase of pig slurry substrate (Ribeiro et al., 2007).

\section{CONCLUSIONS}

The growth substrates used in this study influenced physiological parameters, vegetative and flowering phenological stages, flowering precocity and ornamental value. In this research we found a positive correlation between the number of flowers and the leaf area. The parameters studied were significantly influenced by the type of growing components and the proportion in the mixture. Petunia and ornamental tobacco plants grown in media with $60 \%$ biolan peat, $30 \%$ acid peat and $10 \%$ perlite seem to be high-value ornamental plants, while the value of the plants cultured in media containing fallow soil is too low to be profitable.

\section{LITERATURE CITED}

Ahmad, I., R.U. Saquib, M. Qasim, M. Saleem, A.S. Khan, and M. Yaseen. 2013. Humic acid and cultivar effects on growth, yield, vase life, and corm characteristics of gladiolus. Chilean Journal of Agricultural Research 73:339-344.

Arancon, N.Q., C.A. Edwards, A. Babenko, J. Cannon, P. Galvis, and J.D. Metzger. 2008. Influences of vermicomposts, produced by earthworms and microorganisms from cattle manure, food waste and paper waste, on the germination, growth and flowering of petunias in the greenhouse. Applied Soil Ecology 39:91-99. 
Arancon, N.Q., C.A. Edwards, S. Lee, and R. Byrne. 2006. Effects of humic acids from vermicomposts on plant growth. European Journal of Soil Biology 46:65-69.

Atiyeh, R.M., C.A. Edwards, J.D. Metzger, S. Lee, and N.Q. Arancon. 2002. The influence of humic acids derived from earthworm-processed organic wastes on plant growth. Bioresource Technology 84:7-14.

Bachman, G.R., and J.D. Metzger. 2008. Growth of bedding plants in commercial potting substrate amended with vermicompost. Bioresource Technology 99:3155-3161.

Benito, M., A. Masaguer, A. Moliner, and R.D. Antonia. 2006. Chemical and physical properties of pruning waste compost and their seasonal variability. Bioresource Technology 97:2071-2076.

Bustamante, M.A., C. Paredes, R. Moral, E. Agulló, M.D. PérezMurcia, and M. Abad. 2008. Composts from distillery wastes as peat substitutes for transplant production. Resources, Conservation and Recycling 52:792-799.

Campitelli, P., and S. Ceppi. 2008. Effects of composting technologies on the chemical and physicochemical properties of humic acids. Geoderma 144:325-333.

Castaldi, P., G. Alberti, R. Merella, and P. Melis. 2005. Study of the organic matter evolution during municipal solid waste composting aimed at identifying suitable parameters for the evaluation of compost maturity. Waste Management 25:209-213.

Chavez, W., A. Di Benedetto, G. Civeira, and R. Lavado. 2008. Alternative soilless media for growing Petunia $x$ hybrida and Impatiens wallerana: Physical behavior, effect of fertilization and nitrate losses. Bioresource Technology 99:8082-8087.

Civeira, G. 2010. Influence of municipal solid waste compost on soil properties and plant reestablishment in peri-urban environments. Chilean Journal of Agricultural Research 70:446-453.

Di Benedetto, A., J.C. Petracchi, G. Marcella, P. Montaron, and W. Chavez. 2006. Evaluation of alternative substrates for bedding plants. International Journal of Agricultural Research 1:545-554.

Dole, J.M., and H.F. Wilkins. 2004. Floriculture: Principles and species. $2^{\text {nd }}$ ed. Prentice Hall, Upper Saddle River, New Jersey, USA

Francescangeli, N., and A. Zagabria. 2008. Paclobutrazol for height control of petunias. Chilean Journal of Agricultural Research 68:309-314.

Garcia-Gomez, A., M.P. Bernal, and A. Roig. 2002. Growth of ornamental plants in two composts prepared from agroindustrial wastes. Bioresource Technology 83:81-87.

Gaspar, Y.M., J.A. McKenna, B.S. McGinness, J. Hinch, S. Poon, A.A.Connelly, et al. 2014. Field resistance to Fusarium oxysporum and Verticillium dahliae in transgenic cotton expressing the plant defensin NaD1. Journal of Experimental Botany 65:1541-1550.

Gerats, T., and M. Vandenbussche. 2005. A model system for comparative research: Petunia. Trends in Plant Sciences 10:251-256

Grigatti, M., M.E. Giorgioni, and C. Ciavatta. 2007. Compost-based growing media: Influence on growth and nutrient use of bedding plants. Bioresource Technology 98:3526-3534

Hernández, A., H. Castillo, D. Ojeda, A. Arras, J. López, and E. Sánchez. 2010. Effect of vermicompost and compost on lettuce production. Chilean Journal of Agricultural Research 70:583-589.

Holm, G. 1954. Chlorophyll mutations in barley. Acta Agriculturae Scandinavica 4:457-471.

Medina, E., C. Paredes, M.D. Pérez-Murcia, M.A. Bustamante, and R. Moral. 2009. Spent mushroom substrates as component of growing media for germination and growth of horticultural plants. Bioresource Technology 100:4227-4232.
Mehmood, T., W. Ahmad, K.S. Ahmad, J. Shafi, M.A. Shehzad, and M.A. Sarwar. 2013. Comparative effect of different potting media on vegetative and reproductive growth of floral shower (Antirrhinum majus L.) Universal Journal of Plant Science 1:104-111.

Meier, U. 2001. Growth stages of mono-and dicotyledonous plants. BBCH monograph. German Federal Biological Research Centre for Agriculture and Forestry, Berlin, Germany.

Nazari, F., M. Khosh-Khui, and H. Salehi. 2009. Growth and flower quality of four Rosa hybrida L. cultivars in response to propagation by stenting or cutting in soilless culture. Scientia Horticulturae 119:302-305.

Nishijima, T., H. Miyaki, K. Sasaki, and T. Okazawa. 2006. Cultivar and anatomical analysis of corolla enlargement of petunia (Petunia hybrida Vilm.) by cytokinin application. Scientia Horticulturae 111:49-55.

Ntoulas, N., P.A. Nektarios, and G. Gogoula. 2011. Evaluation of olive mill waste compost as a soil amendment for Cynodon dactylon turf establishment, growth, and anchorage. HortScience 46:937-945

Papafotiou, M., G. Kargas, and I. Lytra. 2005. Olive mill waste compost as a growth medium component for foliage potted plants. HortScience 40:1746-1750.

Papafotiou, M., M. Phsyhalou, G. Kargas, I. Chatzipavlidis, and J. Chronopoulos. 2004. Olive-mill wastes compost as growing medium component for the production of poinsettias. Scientia Horticulturae 102:167-175.

Ribeiro, H.M., A.M. Romero, H. Pereira, P. Borges, F. Cabral, and E. Vasconcelos. 2007. Evaluation of a compost obtained from forestry wastes and solid phase of pig slurry as a substrate for seedlings production. Bioresource Technology 98:3294-3297.

Tognetti, C., M.J. Mazzarino, and F. Laos. 2007. Cocomposting biosolids and municipal organic waste: effects of process management on stabilization and quality. Biology and Fertility of Soils 43:387-397.

Warner, R.M. 2010. Temperature and photoperiod influence flowering and morphology of four Petunia spp. HortScience 45:365-368.

Watharkar, A.D., R.V. Khandare, A.A. Kamble, A.Y. Mulla, S.P Govindwar, and J.P. Jadhav. 2013. Phytoremediation potential of Petunia grandiflora Juss., an ornamental plant to degrade a disperse, disulfonated triphenylmethane textile dye Brilliant Blue G. Environmental Science and Pollution Research International 20:939-949.

Xu, G., R. Huo, and Y. Guo. 2010. Growth and development performance of different Petunia hybrida varieties in Yinchuan region. Journal of Anhui Agricultural Sciences 38:16833-16835.

Zaller, J.G. 2007. Vermicompost as a substitute for peat in potting media: effects on germination, biomass allocation, yields and fruit quality of three tomato varieties. Scientia Horticulturae 112:191-199.

Zhanga, W., X. Li, F. Chenb, and J. Lua. 2012. Accumulation and distribution characteristics for nitrogen, phosphorus and potassium in different cultivars of Petunia hybrida Vlim. Scientia Horticulturae 141:83-90. 